\title{
Trophic Conditions in the Waters of the Venice Lagoon (Northern Adriatic Sea, Italy)
}

\author{
Chiara Facca ${ }^{*}$, Nicola Pellegrino, Sonia Ceoldo, Marta Tibaldo and Adriano Sfriso \\ Department of Environmental Sciences, University Ca' Foscari Venice, Calle Larga Santa Marta, 2137, 30123-Venice, \\ Italy
}

\begin{abstract}
Data on nutrient concentrations and environmental parameters, recorded in the waters of the entire Venice lagoon (165 sites) in July 2003 and in two stations monthly sampled for two years (from April 1994 to March 1995 and from January to December 2005), are reported in order to compare the trophic conditions with the past situation. In summer 2003 the dissolved inorganic nitrogen varied between 0.66 and $41.2 \mu \mathrm{M}$, whereas the reactive phosphorus fluctuated between 0.01 and $1.75 \mu \mathrm{M}$. Values above the imperative values (nitrogen $>25 \mu \mathrm{M}$, phosphorus $>0.81 \mu \mathrm{M}$ ) established by the Italian law were not rare and they were found close to the mainland and the main river outflows. The comparison with previous data to update the knowledge on the trophic conditions of the lagoon showed that the overall trophic load is reducing. Only nitrate concentrations did not change.
\end{abstract}

The seasonal samples allowed to confirm the above observations highlighting the behaviour of nutrients in relation to the weather conditions and to the primary producer fluctuations.

Keywords: Nutrients, water, lagoons, chlorophylls.

\section{INTRODUCTION}

Coastal lagoons in developed countries are commonly characterised by high productivity and poor water quality due to the synergy of several factors, such as high population density in the coastal areas, reduced exchanges with the sea, accumulation of nutrients from the drainage basin, human exploitation of the lagoon natural resources, etc. In fact, over the last four decades, human activities increased nitrogen fluxes into many coastal areas [1] affecting the ecosystem equilibrium. In Europe, the problem was mostly observed in the North Sea [2,3] and along the occidental and southern coastal areas [4]. The open waters of the Mediterranean Sea are considered to be generally good and are classified among the poorest in nutrients of the world oceans [5]. Nevertheless, the major problem of the Mediterranean Sea could be represented by 'hotspots' in coastal areas which pose adverse and persistent local environmental impacts. Such areas are generally located in semi-enclosed gulfs and bays near important harbours, big cities and industrial areas which can be characterised by reduced water movement and circulation patterns. Together with the Gulf of Lion (France), the northwestern coast of the Adriatic Sea is one of the most eutrophicated Mediterranean areas due to several river discharges. One of the first study in such area dealt with Venice Lagoon, Po River delta and the coast of Emilia-Romagna region [6, 7]. The lagoon of Venice represents an important case study due to its important economic, historical and ecological role being the biggest wetland in the Mediterranean eco-region. The eutrophication effects were particularly intense between

*Address correspondence to this author at the Department of Environmental Sciences, University Ca' Foscari Venice, Calle Larga Santa Marta, 2137, 30123-Venice, Italy; Tel: 0039 (0)41 2348529; Fax: 0039 (0)41 2348584; E-mail: facca@unive.it the 1970s and the 1980s. Since the 1920s, when Porto Marghera industrial area began to develop, the discharge of pollutants, trophic substances (phosphorus and nitrogen compounds), and warm waters have heavily affected the lagoon water quality [8]. Moreover, nutrient-enriched sewage is directly discharged into Venice historic centre canals and dispersed in the lagoon by tidal currents and winds $[9,10]$. Although, before the $1970 \mathrm{~s}$, high nutrient concentrations were recorded in the lagoon waters, no evident eutrophication effects were observed [11] as seagrass beds were still widespread. Negative environmental consequences started in the 1970s and peaked in the 1980s, when the chlorophycea Ulva rigida C. Agardh replaced the seagrasses in the whole central lagoon [12]. The abnormal growth and summer decomposition of $U$. rigida seriously affected nutrient and pollutant cycles and the biodiversity of the lagoon, especially in the central and northern basins [12].

The amounts of nutrients conveyed in the lagoon in the 1970s by the discharges of the industrial area of Porto Marghera drastically decreased after the activation of the Fusina and Campalto wastewater treatment plants in 1978 (Table 1, [13]). At the end of 1980s the total nutrient load entering the lagoon by direct (domestic, agricultural and industrial) and indirect (rivers, atmospheric fall out) sources was ca. $8437 \mathrm{t} \mathrm{y}^{-1}$ for $\mathrm{N}$ and $1148 \mathrm{t} \mathrm{y}^{-1}$ for $\mathrm{P}$ (Table 1, [14]). In the most recent years, as a result of both industry decline and the implementation of severe legislation objectives aiming at reducing air and water pollution (Italian Ministerial Decree "Ronchi-Costa decree", April 1998; Italian Ministerial Decree, July 1999), the concentrations of nutrients and of toxic substances in the environment decreased again (Table 1). At the end of the 1990s, in fact, the nitrate load in the Venice lagoon was estimated to be over $3000 \mathrm{t} \mathrm{y}^{-1}$ ( 75\% from the drainage basin and $25 \%$ from atmospheric deposition), the ammonium $\sim 1000 \mathrm{t} \mathrm{y}^{-1}$ 
( $\sim 40 \%$ from the drainage basin and $60 \%$ from atmospheric deposition), the total phosphorus $\sim 300 \mathrm{t} \mathrm{y}^{-1}$ and the phosphate $\sim 80$ t y $^{-1}$ ( $80 \%$ from the drainage basin and $20 \%$ from atmospheric deposition) [15]. During the 1990s also the environmental conditions of the lagoon changed again, as seaweed blooms declined $[12,16]$, mainly because of climatic changes, the increase of sediment re-suspension and the above cited reduction of nutrient loads.

Table 1. Nutrient Loads (tons/ y) in the Venice Lagoon. The Terms "All Sources" Indicates Domestic, Agricultural, Industrial, River and Atmospheric Inputs

\begin{tabular}{|c|c|c|c|c|}
\hline Period & Nitrogen & Phosphorus & Source & Reference \\
\hline \hline early 1970s & 4600 & 1250 & Industrial & {$[13]$} \\
\hline after 1978 & 2100 & 210 & Industrial & {$[13]$} \\
\hline late 1980s & 8437 & 1148 & All sources & {$[14]$} \\
\hline late 1990s & 4000 & 380 & All sources & {$[15]$} \\
\hline 1999 & 1050 & 150 & Industrial & {$[13]$} \\
\hline
\end{tabular}

This paper aims at investigating temporal, seasonal and spatial variations in the lagoon trophic status following the implementation of environmental legislation; this was achieved via the measures of nutrients, chlorophyll $a$ and macrophyte coverage which were carried out once in the whole lagoon and monthly in two stations. This paper would help to draw the evolution of the lagoon environmental conditions through the beginning of the new century.

\section{MATERIALS AND METHODOLOGY}

\subsection{Study Area and Sample Collection}

The Venice lagoon, which is a wide transitional system in the North-western Adriatic Sea (Fig. 1), covers ca. 549 $\mathrm{km}^{2}$, alternating different environmental conditions due to the interactions between human interventions and natural features. Its mean depth is $1-1.2 \mathrm{~m}$, but it has some wide canals and three deep $(15-20 \mathrm{~m})$ and wide $(600-900 \mathrm{~m})$ inlets (Lido, Malamocco, Chioggia). The tidal sea-water flow through the three port inlets amounts approximately to a half of the total volume of the lagoon at each tidal cycle (12 hours). Freshwater inputs are ca. $35 \mathrm{~m}^{3} \mathrm{~s}^{-1} \mathrm{y}^{-1}$ from the 12

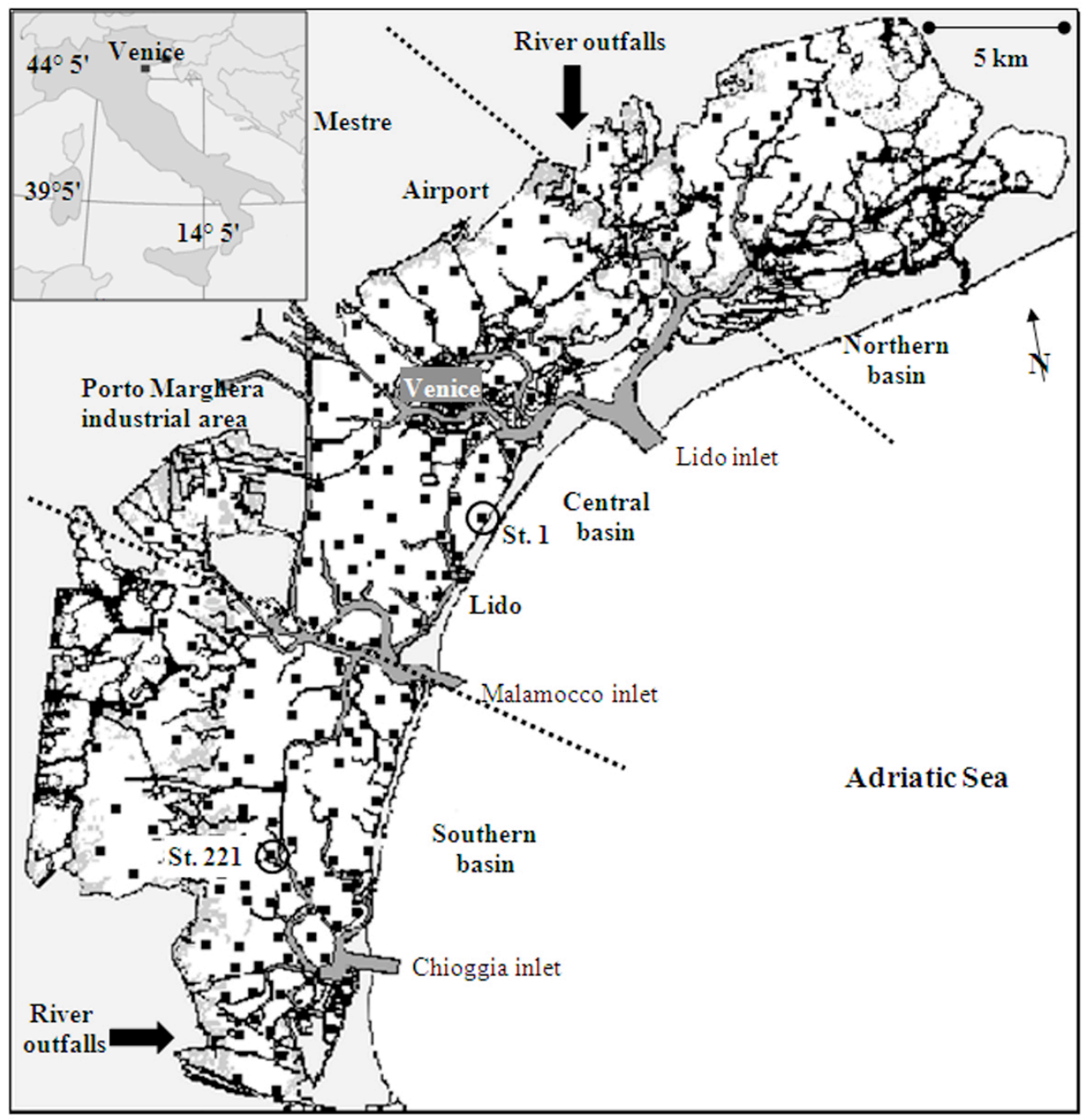

Fig. (1). Lagoon of Venice and sampling sites. The 165 sampling sites are marked by black squares. The circles highlight the two stations (1 and 221) out of the 165 sites which were monthly sampled. The dashed lines mark the ideal separation into morphological basins. 
main tributaries, which account for about $97 \%$ of the whole drainage basin (1850 km², [17]), with peak discharge in stormy conditions of $344 \mathrm{~m}^{3} \mathrm{~s}^{-1}$ [18] and up to $600 \mathrm{~m}^{3} \mathrm{~s}^{-1}$ [19]. The mean tide excursion in the lagoon is ca. $\pm 31 \mathrm{~cm}$ [20] but, under particular tidal events and/or meteorological conditions, values up of $170 \mathrm{~cm}$ above the mean sea level are sometimes observed [21].

In order to facilitate its description, the lagoon was divided into three morphological basins (southern, central and northern basins) which are separated by the MalamoccoMarghera canal in the South and by the Burano-Torcello salt-marshes in the North (Fig. 1). The central basin, where Venice historic centre is located, is the most anthropogenic. It receives untreated sewage from the city and the major islands and treated urban wastewater from Mestre and its hinterland. Moreover, the wide industrial area of Porto Marghera, that has been responsible for nutrient and pollutant enrichment for almost 70 years, insists in this area. In the northern basin some tributaries drain the waters from an intensively cultivated hinterland.

Water samples were obtained by mixing together 5-6 sub-samples of the entire water-column collected by a Plexiglas bottle (height $150 \mathrm{~cm}$, diameter $4 \mathrm{~cm}$ ) in 165 sites during the last week of June 2003 and the first days of July 2003: 69 were placed in the central basin where campaigns were carried out also in the late 1980s and in the 1990s, 77 and 19 were located in the southern and northern basins, respectively. Sampling sites were located in shallow areas, far from the main canals, taking into account the lagoon morphology and the presence/absence of macroalgae and seagrasses. Two out of the 165 sites were monitored monthly for one year from April 1994 to March 1995 and from January to December 2005. The station 1 was located in the central basin whereas the station 221 was in the southern one (Fig. 1).

\subsection{Sample Analyses}

Water temperature $\left(\mathrm{T}\right.$; accuracy $\left.\pm 0.15^{\circ} \mathrm{C}\right), \mathrm{pH}$ (accuracy $\pm 0.015)$ and redox potential $\left(\mathrm{E}_{\mathrm{h}}\right.$; accuracy $\left.\pm 0.15 \%\right)$ were obtained by a portable pH-meter (model HD 8705, delta OHM, Padua, Italy). Water oxygen saturation (Ox; accuracy $\pm 0.5 \%$ ) was measured by an oximeter (Oxi 330i, Wissenschaftlich-technische Werkstätten GmbH, Weilheim, Germany) equipped with a battery stirrer BR 190. Data were transformed in saturation percentage depending on water temperature and chlorinity. Salinity ( $\mathrm{S}$; experimental error $0.5 \%$ ) was determined according to the formula by Knudsen after argentometric determination [22]. Water transparency was measured by means of the Secchi disk and the extinction depth was expressed as percentage of the water column depth, to obtain results which can be comparable independently from the water depth. A value of $100 \%$ means that the bottom was visible; a value of $50 \%$ means that the disk disappeared half way from the bottom.

Water aliquots, ranging from 500 to $1000 \mathrm{ml}$, were filtered through $\mathrm{GF} / \mathrm{F}$ glass fibre filters (ca $0.7 \mu \mathrm{m}$ ) and frozen at $-20{ }^{\circ} \mathrm{C}$ till nutrient determinations. In the laboratory nitrites (experimental error 5\%), nitrates (experimental error $5 \%$ ), ammonium (experimental error 10\%) and reactive phosphorous (RP; experimental error 5\%) concentrations were determined according to the Strickland and Parson's procedures [23]. Dissolved Inorganic Nitrogen (DIN) was calculated as the sum of nitrites, nitrates and ammonium.

Phytoplankton was monitored as chlorophyll $a$ (Chl- $a$; experimental error $15 \%$ ) concentrations by using the $\mathrm{GF} / \mathrm{F}$ glass fibre filters $(\mathrm{ca} 0.7 \mu \mathrm{m})$ stored at $-20^{\circ} \mathrm{C}$ till the pigment determination [24].

Macrophyte biomass was recorded within ranges in relation to fresh-weights and coverage. The sampling methods and the results are widely discuss elsewhere [25, 26]; here, such data were retrieved for the statistical analyses, described below, in order to complete the trophic profile of the lagoon.

\subsection{Statistical Analyses}

All the data were processed in order to determine means, standard deviations and maximum and minimum values.

Pearson correlation coefficients ( $r$ ) indicate the strength and direction of a linear relationship between variables; $r$ was considered significant when $p$-value $<0.05$. Principal Component Analysis (PCA) elaborates data in order to reduce the number of variables revealing the internal structure of the dataset in a way which best explains the variance. The results were displayed on a bi-dimensional plot and the significant loadings were marked when $\geq|0.7|$. On the basis of the PCA output, multiple regressions were carried out to preview the nutrient, Chl- $a$ and macrophyte trends. The general purpose of multiple regressions is to learn more about the relationship between several independent or predictor variables and a dependent variable. Only the significant coefficients $B(p<0.05)$ are reported and they are listed in relation to their loadings (beta coefficient values). All the data were processed by using the software Statistica v. 7.1 (StatSoft, Tulsa, OK, 74104, 2005 edition).

If both 1998 and 2003 observations were available for the same site (on the whole 46 stations in the central lagoon) the data were compared by means of one-way ANOVA in order to evaluate if their difference was significant ( $p$-value $<0.05$ ). The same was applied to the data from stations 1 and 221 , for which two complete seasonal trends were recorded.

The main physico-chemical parameters and the nutrient concentrations were plotted in maps by using the Surfer mapping system (Golden Software Inc., 1993-2000) by means of kriging method.

\section{RESULTS}

\subsection{Physico-Chemical Parameters}

The separation of the lagoon in three basins allow to highlight important spatial differences not only in the nutrient concentrations, as will be described in the next paragraph, but also in the physico-chemical parameter values. The central basin displayed, in fact, the lowest temperature, salinity and $\mathrm{pH}$ and the highest turbidity (Fig. 2). In summer 2003, which was particularly warm and poorly rainy, salinity reached 43 in an area of the northern basin with high residence time (Fig. 3). The southern lagoon displayed clear waters (Secchi disk: 100\%) in most of the 

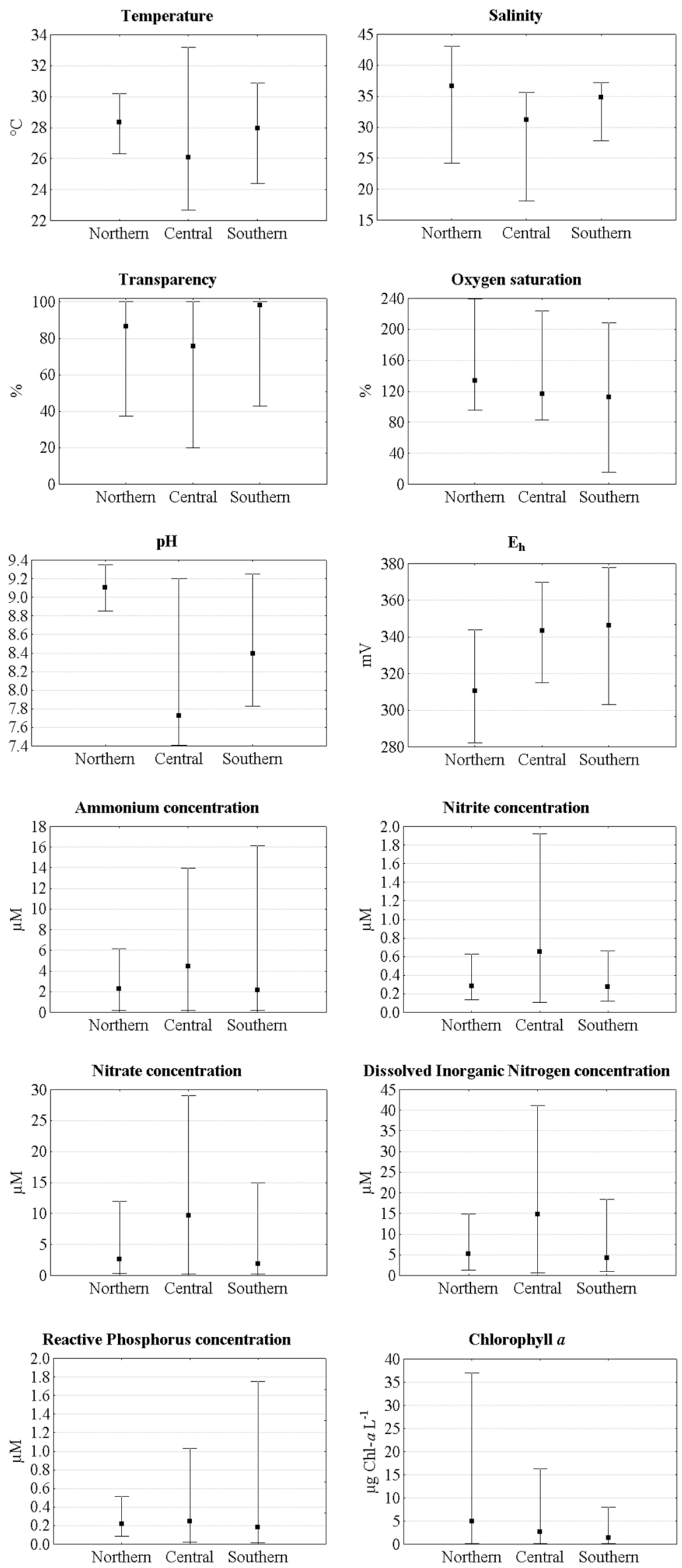

Fig. (2). Means and minimum-maximum values of the considered variables. The three basins were compared: northern basin (19 stations), central basin (69 stations), southern basin ( 77 stations). 
sites (Fig. 3), while turbidity (Secchi disk: 20\%) was high in front of the Porto Marghera industrial area and North of Venice near Marzenego, Dese and Siloncello river outfalls.
Although oxygen concentrations were undersaturated close to the mainland and salt marshes, most of the sites presented over-saturation conditions (Fig. 3) with a mean value of
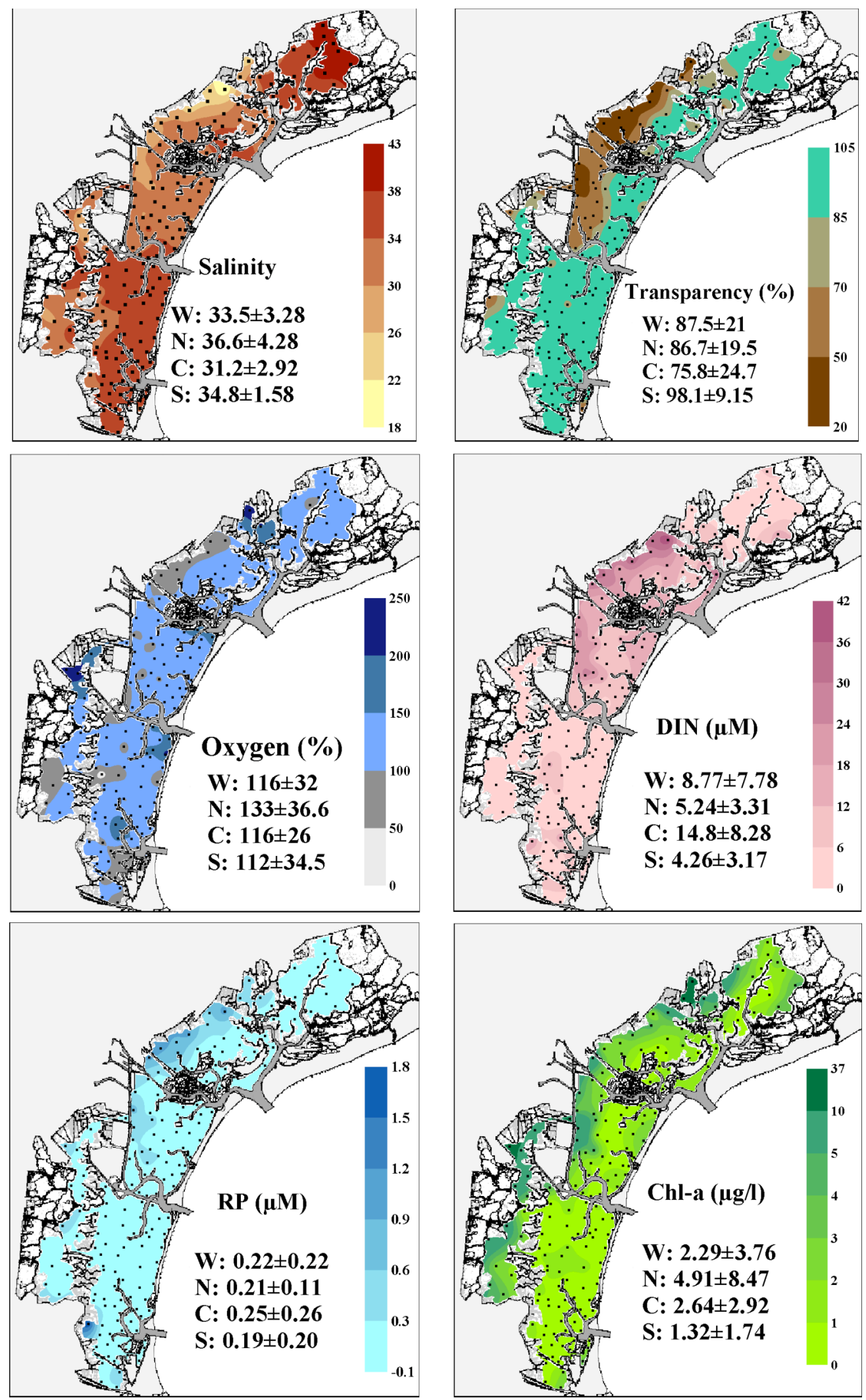

Fig. (3). Spatial distribution maps of salinity, Secchi disk extinction depth (transparency), oxygen saturation (Oxygen), dissolved inorganic nitrogen (DIN), reactive phosphorus (RP) and chlorophyll a (Chl- $a$ ) concentrations are plotted. Means and standard deviations are reported for the whole lagoon $(\mathrm{W})$ and separately for northern $(\mathrm{N})$, central $(\mathrm{C})$ and southern $(\mathrm{S})$ basins. 
$120 \%$ (Fig. 2). The redox potential $\left(E_{\mathrm{h}}\right)$ ranged from $282 \mathrm{mV}$ to $378 \mathrm{mV}$ with a mean value of $341 \pm 20 \mathrm{mV}$ in the whole lagoon (Fig. 2). The values recorded at Sts 1 and 221 in 1994-95 and 2005 ranged between $5.2^{\circ} \mathrm{C}$ and $29.3^{\circ} \mathrm{C}$ for water temperature and between 26.6 and 36.3 for salinity (Fig. 2). Significant (one-way ANOVA p-value $<0.05$ ) $\mathrm{pH}$ decreases were observed at both stations between 1994/95 (annual mean: 8.35) and 2005 (annual mean: 8.00). The redox potential $\left(\mathrm{E}_{\mathrm{h}}\right)$ showed a significant reduction as well (1994/95 annual mean: $355 \mathrm{mV} ; 2005$ annual mean: 318 $\mathrm{mV}$ ). The oxygen saturation values were $>100 \%$ throughout the sampling periods.

\subsection{Nutrient Concentrations}

The nutrient concentrations was widely heterogeneous as shown by both ammonium and nitrate concentrations. The former ranged from $0.20 \mu \mathrm{M}$, in an isolated area close to Porto Marghera, to $16.2 \mu \mathrm{M}$ in proximity of the river outfalls in the southern basin. The latter fluctuated between $0.22 \mu \mathrm{M}$, in the central zone of the southern basin, and $29 \mu \mathrm{M}$, near the airport (Fig. 2). However, the highest values were always recorded in the central basin, where ammonium $(4.44 \pm 2.88$
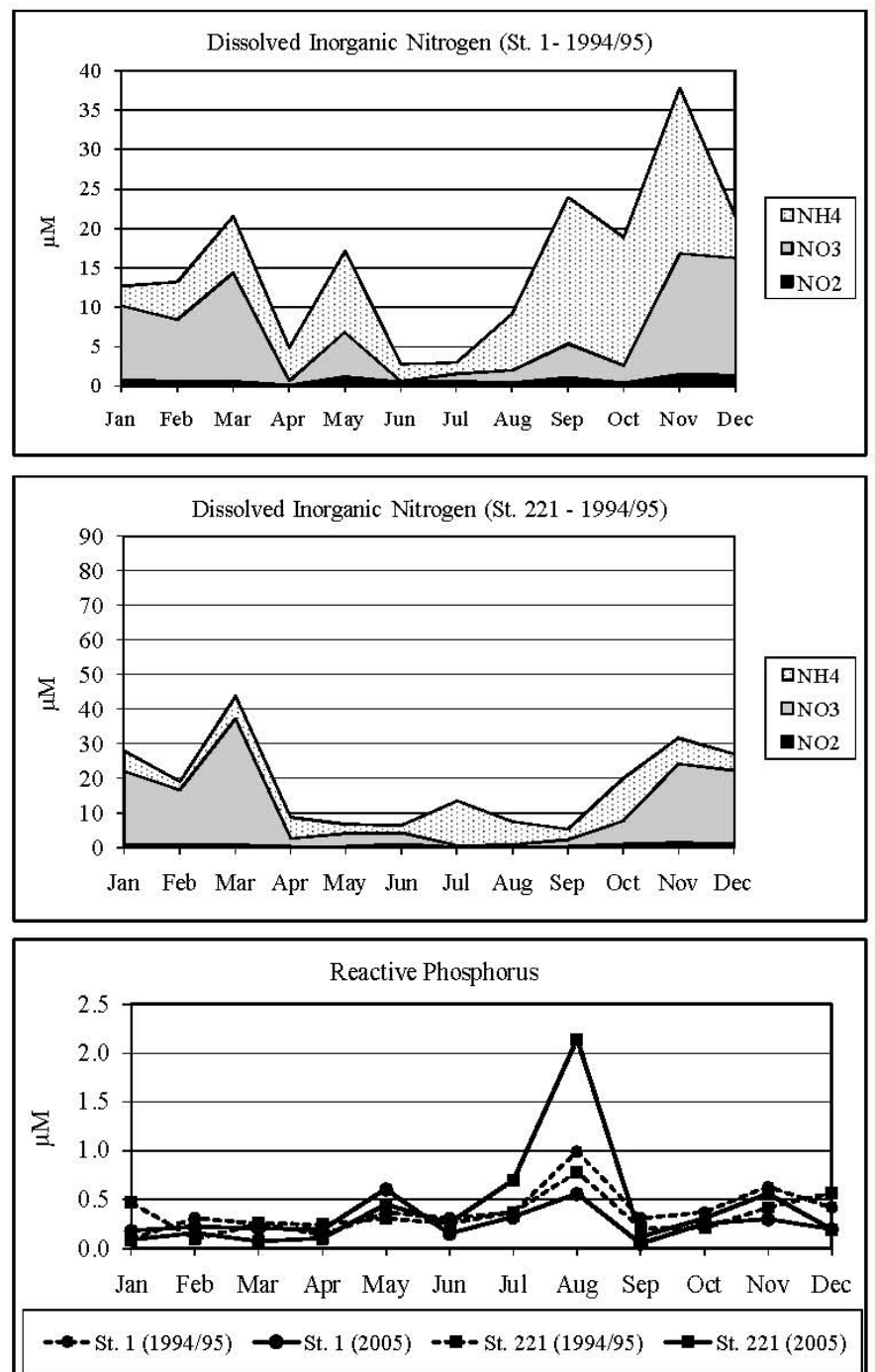

$\mu \mathrm{M})$ was twice and nitrates were $4-5$ times $(9.69 \pm 5.86 \mu \mathrm{M})$ as high as in the other basins (Fig. 2). The nitrite concentrations were about one order of magnitude lower than those of ammonium and nitrates. The mean value was $0.43 \pm 0.32$ $\mu \mathrm{M}$ for the entire lagoon, ranging from 0.11 to $1.93 \mu \mathrm{M}$.

The seasonal trends of ammonium concentrations displayed significant variations: in 2005 at St. 221, which was colonised by the seagrass Nanozostera noltii (Hornemann) Tomlinson et Posluzny and Ulva rigida C. Ag., the values ranged between 1.37 and $82 \mu \mathrm{M}$ (Fig. 4), being the highest in summer and fall. A clear seasonal pattern was observed for nitrate concentrations which were low during spring and summer and high during fall and winter (Fig. 4): at St. 221 in 1994/95, the concentrations were almost negligible (ca. 1 $\mu \mathrm{M}$ ) in June-July and peaked to $36 \mu \mathrm{M}$ in March (Fig. 4). Even though the nitrite concentrations displayed marked seasonal variations their values hardly exceeded $2 \mu \mathrm{M}$. In general, the trends were bimodal with a peak in May-June and the second in September-October (Fig. 4).

The great part of the observations displayed a nitrate contribute to the DIN concentration $>50 \%$, but few stations
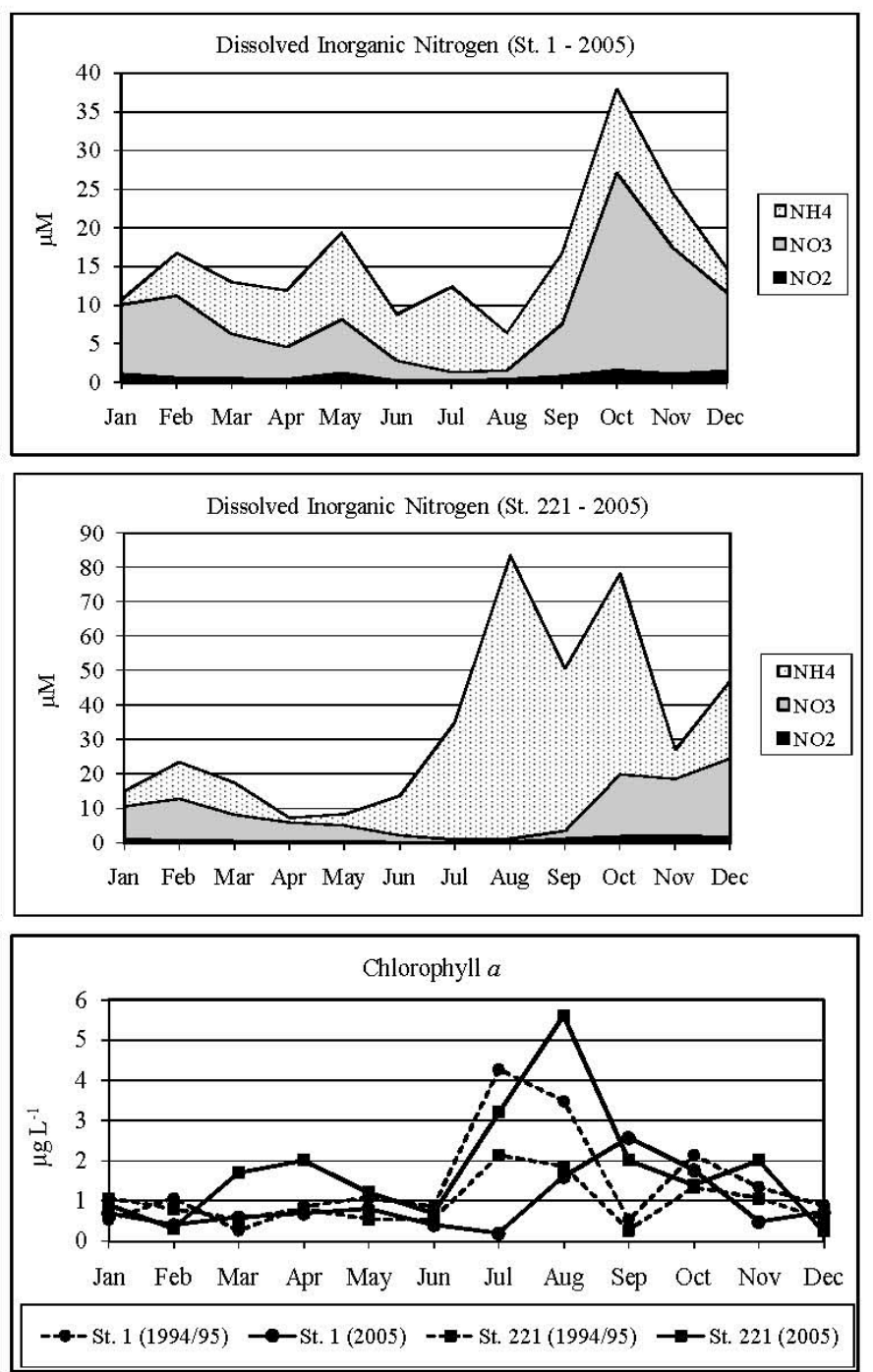

Fig. (4). Nutrient and chlorophyll seasonal trends at the sites 1 and 221 in 1994/95 and 2005. Dissolved inorganic nitrogen was plotted as sum of the three fractions (ammonium $\mathrm{NH}_{4}$, nitrate $\mathrm{NO}_{3}$, nitrite $\mathrm{NO}_{2}$ ). 
in southern basin accounted an ammonium concentration $>80 \%$. Close to the Lido inlet the nitrate contribute was $>80 \%$. The overall DIN mean concentration was $8.77 \pm 7.78$ $\mu \mathrm{M}$, but in the central basin it was $14.8 \pm 8.28 \mu \mathrm{M}$ (Fig. 3). The monthly observations highlighted that ammonium could represent up to $98 \%$ of DIN concentrations during summer in areas covered by seaweed or seagrass meadows. However, such contribute underwent important fluctuations as in early spring, in the same year and at the same site, it dropped to $19 \%$.

In summer 2003, the three basins showed quite similar Reactive Phosphorus (RP) concentrations, which ranged from $0.01 \mu \mathrm{M}$ to $1.75 \mu \mathrm{M}$, with a mean of $0.22 \pm 0.22 \mu \mathrm{M}$ (Fig. 3). The bulk of the sites were characterised by values $<0.4 \mu \mathrm{M}$. RP trends showed two peaks throughout the year: the former was in May and the latter, the highest, in August (Fig. 4).

Comparing the 1994/95 seasonal trends recorded at Sts 1 and 221 with the 2005 ones, only ammonium concentrations appeared to be significantly increased (one-way ANOVA $\mathrm{p}<0.05)$ in the latter stations.
In summer 2003, the mean Chl- $a$ concentration was $2.29 \pm 3.76 \mu \mathrm{g} \mathrm{L}^{-1}$ (Fig. 3). The highest value $\left(37.0 \mu \mathrm{g} \mathrm{L}^{-1}\right)$ was found in the northern basin close to the river outfalls and the lowest one $\left(0.10 \mu \mathrm{g} \mathrm{L}^{-1}\right)$ in the southern basin near the Malamocco-Marghera canal. Comparing the three basins, the mean concentrations displayed a decreasing gradient NorthSouth from $4.91 \pm 8.47 \mu \mathrm{g} \mathrm{L}^{-1}$ to $1.32 \pm 1.74 \mu \mathrm{g} \mathrm{L}^{-1}$ (Fig. 2). Moreover, the values were generally higher close to the mainland than near the port-entrances creating a east-west gradient. The annual mean was $1.27 \mu \mathrm{g} \mathrm{\textrm {L } ^ { - 1 }}$ and the phytoplankton main bloom always occurred in July-August but Chl- $a$ did not exceed $6 \mu \mathrm{g} \mathrm{L}^{-1}$ (Fig. 4).

\subsection{Statistical Analyses}

The summer dataset allowed to highlight the spatial distribution of the considered parameters putting in evidence their relationships. All nutrient concentrations were inversely correlated with salinity and water transparency whereas the temperature and $\mathrm{pH}$ were negatively correlated only with DIN and its fractions. Chl- $a$ was inversely correlated with the water transparency, salinity and macrophytes, whereas it

Table 2. Pearson's Coefficients for the Summer Data Set (165 Cases x 14 Variables). The Highly Significant Coefficients ( $r>|0.26|)$ per $\mathbf{p}<\mathbf{0 . 0 0 1}$ are Reported and Negative Correlation are in Bold

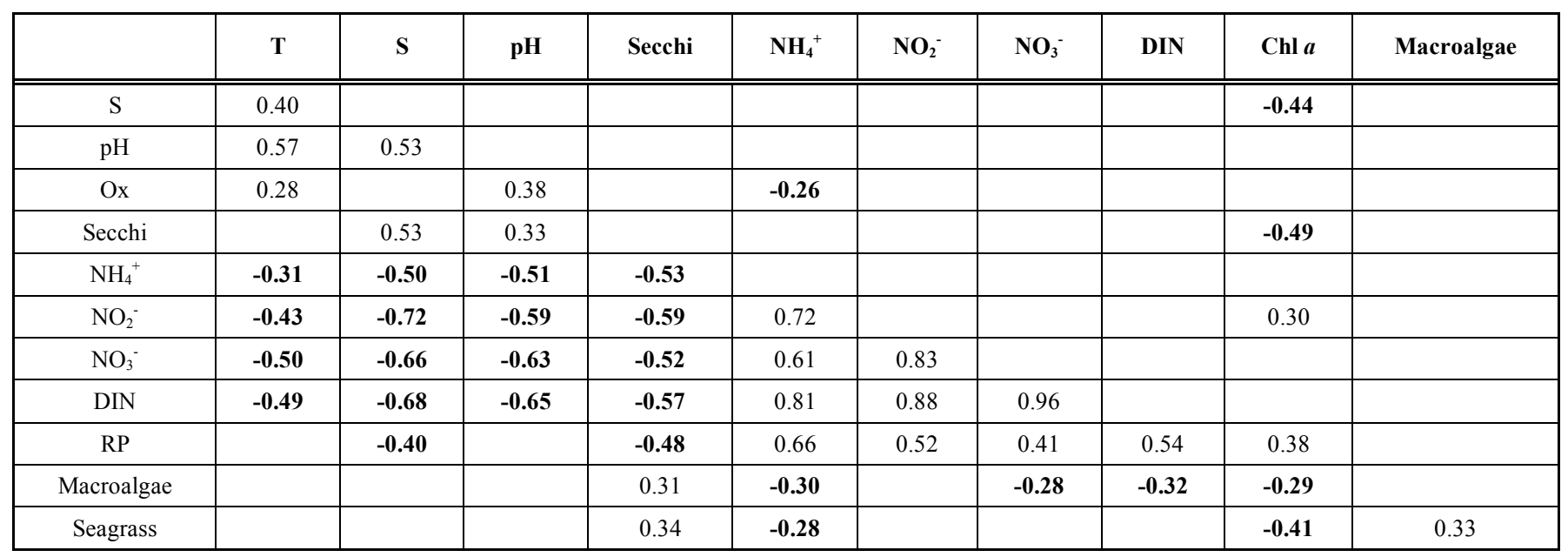

Table 3. Pearson's Coefficients for the Seasonal Data Set (48 Cases $x 13$ Variables). The Significant Correlation per $p<0.05$ $(r>|0.30|)$ are Reported and, in Bold, are the Highly Significant Coefficients per $p<0.001(r>|0.47|)$

\begin{tabular}{|c|c|c|c|c|c|c|c|c|c|}
\hline & $\mathbf{T}$ & $\mathbf{S}$ & pH & Secchi & $\mathbf{N H}_{4}{ }^{+}$ & $\mathrm{NO}_{2}^{-}$ & $\mathrm{NO}_{3}^{-}$ & $\mathbf{R P}$ & Chl $a$ \\
\hline $\mathrm{S}$ & & & -0.41 & & & & & & \\
\hline$E_{h}$ & & -0.47 & 0.52 & & & & & & \\
\hline Ox & 0.36 & & & & & & & & \\
\hline Secchi & 0.61 & & -0.42 & & & & & & \\
\hline FPM & 0.42 & & & 0.32 & & & & 0.48 & 0.51 \\
\hline $\mathrm{NO}_{2}^{-}$ & -0.36 & & & -0.46 & & & & & \\
\hline $\mathrm{NO}_{3}{ }^{-}$ & -0.60 & & & -0.56 & & 0.64 & & & \\
\hline DIN & & & & & 0.87 & 0.47 & 0.46 & 0.45 & \\
\hline Chl $a$ & 0.42 & & & & 0.45 & & & 0.56 & \\
\hline
\end{tabular}




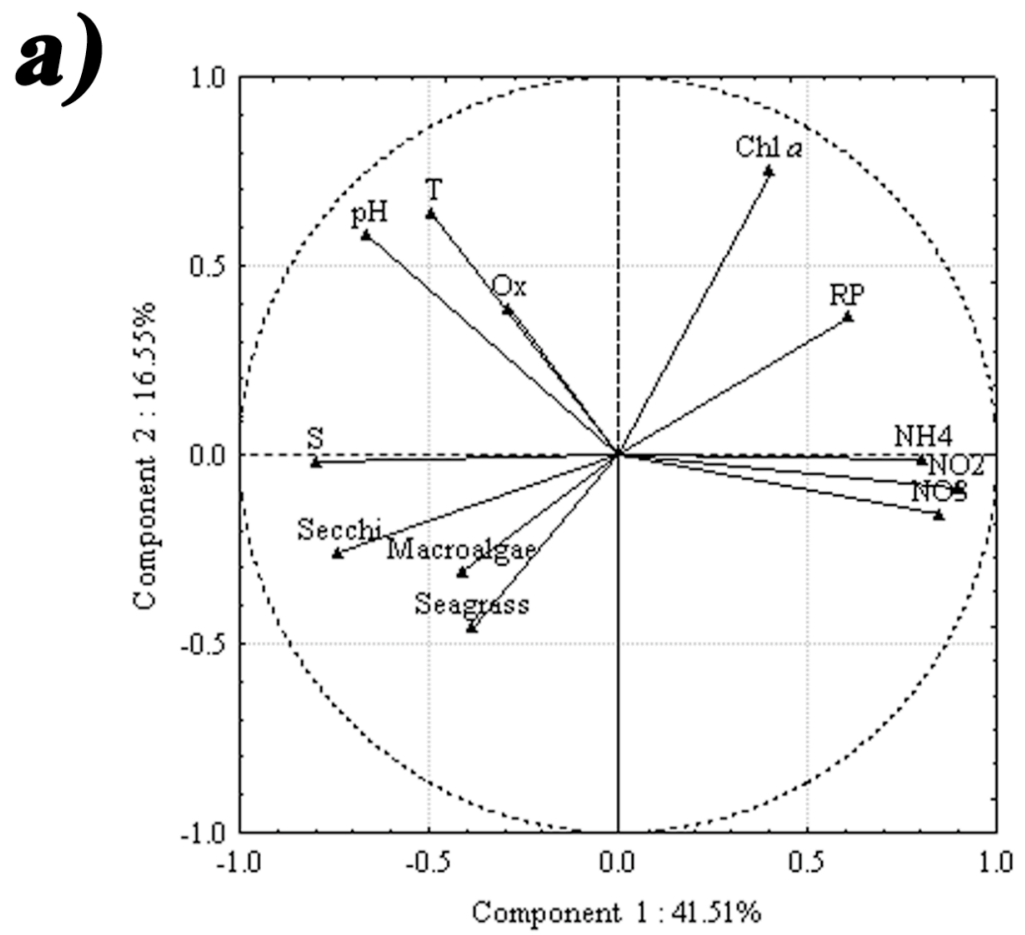

b)

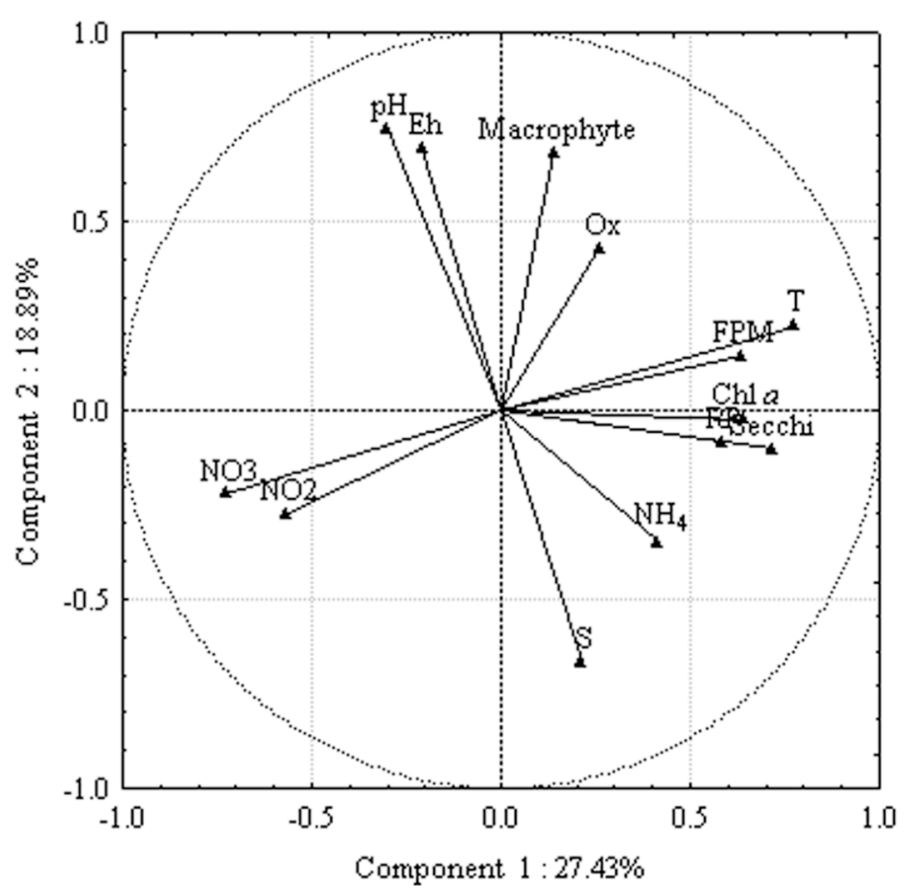

Fig. (5). Loading plots of the Principal Component Analysis (PCA) reported the results of the elaborations carried out with spatial (a) and seasonal (b) datasets. In the axis title of each component the explained variance is reported. Temperature: T; Salinity: S; Ox: Oxygen saturation; Transp: Transparency; $\mathrm{NH}_{4}^{-}$: ammonium; $\mathrm{NO}_{3}^{-}$: nitrate; $\mathrm{NO}_{2}^{-}$: nitrite; $\mathrm{RP}$ : reactive phosphorus; Chl- $a$ : chlorophyll $\alpha$.

showed direct correlations with RP and nitrites. Macroalgae and seagrass were positively correlated with water transparency and negatively with ammonium. Significant correlations occurred also among nutrients (Table 2).

The dataset composed by the two stations monitored seasonally showed that the salinity was not correlated with nutrient concentrations and that the role of temperature was relevant only for nitrates. Chl- $a$ had significant positive correlations with ammonium, phosphorus, temperature and suspended matter. Macrophytes, on the contrary, depended on the salinity (Table 3). The Principal Component Analysis of the summer dataset (PCA, Fig. 5a) explained a variance of $58 \%$ when 2 factors were considered. The variance of the first component was explained by the positive and significant loadings of the ammonium, nitrite and nitrate concentrations which were highly correlated each other, whereas the negative contributions were mainly due to the salinity and the water transparency. The second component had only the significant loading of Chl- $a$. 
Table 4. Multiple Regressions for the Summer Data Set (165 Cases x 12 Variables). Only Significant Coefficients (B) per p-Value $<0.001$ are Reported

\begin{tabular}{|c|c|c|c|c|c|c|c|c|c|c|c|c|c|c|c|c|}
\hline & & & & & & & & & & & & & & & $\mathbf{R}^{2}$ & $\mathbf{p}<$ \\
\hline DIN & $=$ & 100 & - & 6.13 & $\mathrm{x}$ & pH & + & 13.1 & $\mathrm{x}$ & $\mathbf{R P}$ & - & 0.82 & $\mathrm{x}$ & $\mathbf{T}$ & 0.74 & 0.001 \\
\hline $\mathbf{R P}$ & $=$ & -2.08 & + & 0.02 & $\mathrm{x}$ & DIN & + & 0.160 & $\mathrm{x}$ & $\mathbf{p H}$ & + & 0.035 & $\mathrm{x}$ & $\mathbf{T}$ & 0.51 & 0.001 \\
\hline Chl- $a$ & $=$ & -0.06 & + & 0.23 & $\mathrm{x}$ & pH & - & 0.005 & $\mathrm{x}$ & Secchi & + & 0.04 & $\mathrm{x}$ & $\mathbf{T}$ & 0.33 & 0.001 \\
\hline
\end{tabular}

Table 5. Multiple Regressions for the Seasonal Data Set (48 Cases x 12 Variables). Only Significant Coefficients (B) per p-Value $<0.05$ are Reported

\begin{tabular}{|c|c|c|c|c|c|c|c|c|c|c|c|c|c|c|c|c|c|c|c|c|}
\hline & & & & & & & & & & & & & & & & & & & $\mathbf{R}^{2}$ & $\mathbf{p}^{<}$ \\
\hline \hline $\mathbf{N O}_{2}^{-}$ & $=$ & 0.032 & $\mathrm{x}$ & $\mathbf{N O}_{3}^{-}$ & & & & & & & & & & & & & & & 0.57 & 0.001 \\
\hline $\mathbf{N O}_{3}^{-}$ & $=$ & -0.49 & $\mathrm{x}$ & $\mathbf{T}$ & + & 6.81 & $\mathrm{x}$ & $\mathbf{N O} \mathbf{O}_{2}^{-}$ & - & 1.35 & $\mathrm{x}$ & $\mathbf{S}$ & - & 8.8 & $\mathrm{x}$ & \multicolumn{2}{|c|}{ Macrophytes } & 0.67 & 0.001 \\
\hline $\mathbf{R P}$ & $=$ & 0.01 & $\mathrm{x}$ & $\mathbf{N H}_{4}$ & + & 0.01 & $\mathrm{x}$ & $\mathbf{F P M}$ & + & 0.004 & $\mathrm{x}$ & $\mathbf{E h}$ & - & 0.42 & $\mathrm{x}$ & $\mathbf{p H}$ & & & 0.65 & 0.001 \\
\hline
\end{tabular}

Concerning the seasonal dataset, the first two components in the PCA explained a variance of $46 \%$. The significant loadings in the first component were temperature, transparency and nitrate concentration, whereas only $\mathrm{pH}$ was significant in the second component (Fig. 5b).

Multiple regression results are reported in Tables $\mathbf{4}$ and $\mathbf{5}$ where $\mathrm{R}^{2}$ indicates the variance explained by the formula and $p$ gives the significance of the fitting. As in the PCA of the summer dataset the three nitrogen fractions had similar loadings (Fig. 5a), in this multiple regression DIN was considered as a unique variable. The analyses processed considering alternatively DIN, RP and Chl- $a$ as dependent variables had all highly significant fittings $(\mathrm{p}$-value $<0.001)$ but the highest variance was explained by DIN (74\%; Table 4). When macroalgae and seagrass were considered as dependent variables the fitting was poorly significant.

The PCA, processed by means of the seasonal dataset, highlighted that the variability pattern of nitrate was different from the ammonium one, having opposite loadings along the first axis. Weighing up such results, the multiple regression was performed considering as dependent variables, alternatively, nitrates $\left(\mathrm{NO}_{3}{ }^{-}\right)$, nitrites $\left(\mathrm{NO}_{2}{ }^{-}\right)$, ammonium $\left(\mathrm{NH}_{4}{ }^{+}\right)$, $\mathrm{RP}, \mathrm{Chl}-a$ and macrophytes. Only $\mathrm{NO}_{3}{ }^{-}, \mathrm{NO}_{2}{ }^{-}$and RP had significant fittings per $\mathrm{p}<0.001$ (Table 5). The most interesting results were achieved for the $\mathrm{NO}_{3}^{-}$which variability could be predicted by temperature, nitrites, salinity and macrophyte variations.

\section{DISCUSSION}

The lagoon of Venice is a heterogeneous ecosystem with impressive socio-economical interests (fish, tourism, industry...), so it is not surprisingly that its safeguarding is among the most challenging objective both on national and international scale. Its environmental conditions are frequently monitored and deeply studied in order to prevent dystrophic crisis occurrences, which might damage the fishing activity and threaten human health. After the experience of the $U$. rigida proliferation in the 1980s several actions were taken to reduce its growth and development (biomass harvest, phosphorus ban), even though the climatic changes appeared to have been the main hampering factor $[12,16]$.

Some significant changes of the lagoon conditions were already observed back in 1998, when, in the central lagoon some parameters, which are strongly related to the macrophytes (oxygen saturation, $\mathrm{pH}$ and $\mathrm{E}_{\mathrm{h}}$ ) decreased progressively in the water column $[12,27]$. The same trend was still confirmed by the present results, in particular, $\mathrm{pH}$ and $E_{h}$, compared with the 1990s conditions, showed highly significant reductions (Fig. 6). Considering that a high primary production, at first, depletes the dissolved $\mathrm{CO}_{2}$ in the water column and then the bicarbonates raise the $\mathrm{pH}$ value [28], it is not surprising that $\mathrm{pH}$ has lowered after the macrophyte reduction in the whole lagoon $[12,25]$. In 5 years the mean $\mathrm{pH}$ in the central basin lowered of 0.4 units (Fig. 6). Even though such rapid variation was mainly related to modifications of the local primary production and it could not be related to the global ocean acidification triggered by the $\mathrm{CO}_{2}$ emission, it may represent a critical factor for the organisms which need to adapt or acclimate to new chemical conditions [29]. So for the future, it must be considered that this aspect will probably require much attention.

In the early 2000 s, the absence of huge macroalgae biomass [25] and hence of high primary productivity, determined the flattening of the oxygen saturation variations which sporadically dropped below $100 \%$ but without dramatic consequences. Similar results were achieved for the water transparency which decreased during the 1990s but remained almost constant in the early 2000 s being mainly driven by physical and anthropic factors.

The eutrophication phenomena depend on a synergy of different factors: nutrient enrichment alone can not necessarily determine the rise of the basin trophic level being important also the hydrodynamism and the basin morphology [30]. In fact, in the Venice lagoon nutrients were massively discharged in the after-Second World War period but the eutrophication effects have become evident since the 1970 s, even though in that period waste-water treatment 

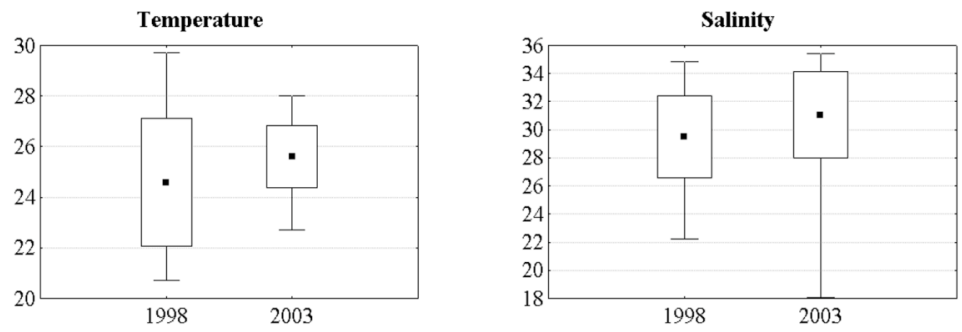

- MEAN

STANDARD

DEVIATION

\section{MIN-MAX}
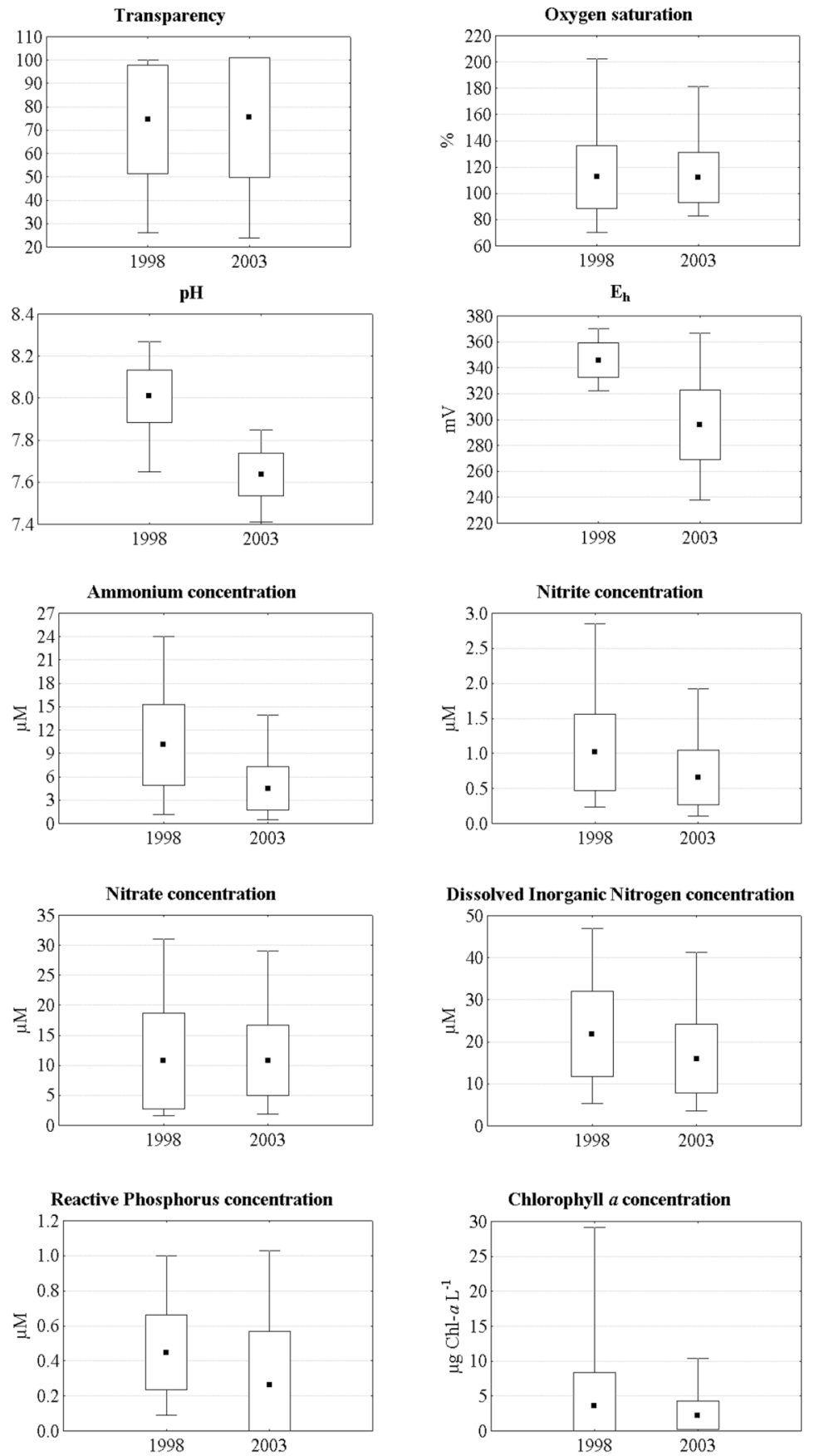

Fig. (6). The summer 2003 data in the central basin were compared with the values collected in summer 1998.

plants were built [13]. In the 1960s-1970s, the ammonium concentrations peaked in the canals of the industrial area (ca. 2600-3800 $\mu \mathrm{M}$ ) and in the adjacent shallow bottoms (ca.
1000-2500 $\mu \mathrm{M}$; $[13,31])$, but, back in summer 1998, they were $\sim 15 \mu \mathrm{M}$ just near Porto Marghera. The present data still reported a highly significant ammonium reduction (Fig. 6) 
with values ranging between 3 and $10 \mu \mathrm{M}$, near the industrial area. The peak value $(16.5 \mu \mathrm{M})$ was observed near Venice airport, probably because of the presence of the treatment plant, that drains the sewage from the hinterland. The reduction of ammonium emissions from the industrial area was probably the main cause of the progressive decrease of its concentration in the whole central lagoon [13]. An exception to this trend was observed at St. 221 in summer 2005, when ammonium peaked up to $80 \mu \mathrm{M}$. In that case a decomposition of $U$. rigida bed and adverse meteorological conditions determined a massive release of nutrients in the water column leading to values 3-4 times as high as the winter and spring periods. However, so significant fluctuations were limited to the areas with low water exchange and conspicuous macroalgae biomass. In most parts of the lagoon, due to the expansion of seagrass beds (especially Cymodocea nodosa (Ucria) Asch. and Zostera marina L.), which generally favour more stable environmental conditions, and low macroalgal biomass $[12,25]$, ammonium concentrations remained generally under $20 \mu \mathrm{M}$.

On the other hand, the reduction of nitrates in the last decades has been less marked as they are employed as fertilizer in agriculture entering the lagoon mainly by runoff. The significant negative correlation with salinity and the coefficients in the multiple regressions highlighted that carrier as the main responsible for the nitrate enrichment. This confirms the previous observations [33] that recorded nitrate peaks close to river inputs. During the 1960 s and the 1970s, nitrate concentrations ranged between 50 and $70 \mu \mathrm{M}$, whereas in summers 1998 and 2003, they were 15-20 and 20-30 $\mu \mathrm{M}$, respectively (such difference was not statistically significant; Fig. 6). The DIN pattern over the 1980s and the 1990s was driven by the ammonium trend showing a progressive and constant reduction which was not observed for nitrates. However, some authors [33] found that DIN concentrations were higher in springs 1997-2002 than in springs 1975-1979 when massive macroalgal biomass lacked and so there was a markedly minor nitrate uptake [32]. The determinant role of macrophytes in the regulation of biogeochemical cycles and, in particular, in nitrate concentrations [34], was highlighted also by the multiple regression of Table 5. Even though macroalgal biomass has markedly decreased since the mid 1990s [25], their biomass remained still important to affect nitrate concentrations, above all on a seasonal scale. The mean DIN concentration reached in summers 1975-1979 in euhalyne waters [33] is in agreement with the mean value observed in the whole lagoon in summer 2003. In the recent years, DIN concentrations exceeded the imperative law value of $25 \mu \mathrm{M}$ (Italian Ministerial Decree "Ronchi-Costa decree", April 1998; Italian Ministerial Decree, July 1999) close to the mainland between the Venice translagoon bridge and the main river outflows in the North, mainly due to nitrate inputs.

The most drastic reduction was observed for RP which mean, in summer 2003, was twice as low as in 1998 (Fig. 6). Severe laws and the banning from detergents in 1989 caused a strong change of phosphorus input in the lagoon. Few values exceeded the imperative law value of $0.8 \mu \mathrm{M}$ in areas of the central basin closed to the mainland and affected by river outflows. On the whole, our data and the statistical analyses indicate that the main amount of RP depended on the existing stocks stored in the surface sediments being independent of new inputs. In fact, in the multiple regressions, RP did not depend on salinity variations as it was observed for DIN and in particular for nitrates. As a consequence, due to its low concentrations in water column and its marked decrease also in surface sediments [35] RP is considered the main limiting factor for the primary production. The RP annual trends appeared rather constant with the only exception of the St. 221 in August 2005 when macrophytes collapsed enriching the water column.

Concerning the biological parameters, the most unexpected result was the multiple regression of Chl- $a$ for which nutrient concentrations were not among the predictor variables (Tables 4 and 5). Chl- $a$ was correlated with nutrients, and in particular with RP (Tables 2 and 3), but their concentrations did not allow to predict Chl- $a$ amount. Such lack lets suppose that the nutrients were not limiting for phytoplankton growth and that other factors (probably physical factors) influenced the microalgae primary production as the Chl- $a$ concentrations were rather low in comparison with the trophic load. The highest correlation coefficients were found with the transparency but they were negative meaning that the water transparency did not depend on the Chl- $a$ contribute but it was due to inert particle resuspended from sediments as previously observed [36]. So the high sedimentation and water turbidity, reducing the photosynthetically available radiation, should be the main parameters negatively affecting the phytoplankton growth. In fact, in 1990s, the harvesting of Tapes philippinarum Adams $\&$ Reeve became the main halieutic activity in the lagoon with 35000-40000 tons of clams per year [37]. The clam collection occurs by means of mechanical and hydraulic dredging systems which penetrates $20-30 \mathrm{~cm}$ in the sediments destroying the bottom and enhancing the sediment resuspension with rates that, in few years, increased of approximately one order of magnitude. In 2000s the clam production decreased to 25000 tons/y due to more severe controls and probably to a stock reduction but many works carried out to preserve tidal lands and the lagoon morphology contributed to maintain high the water turbidity [38, 39].

\section{CONCLUSIONS}

The overall picture of the lagoon conditions lets us evidence an important reduction of the trophic level in the water column above all for ammonium and phosphorus concentrations. Hence, the policy for the reduction of the nutrient loads appeared to have been successful although something remains to do concerning nitrates whose concentrations are as high as thirty years ago. However, the observed trophic conditions are not comparable with the situations which triggered the invasive macroalgal blooms recorded in the past. On the contrary, in the areas where the waters are more transparent, the conditions are favourable for seagrass spreading [27]. The lagoon which displayed a wide range of different habitats is still changing towards a new equilibrium mainly addressed to good conditions in term of the trophic state, but the activities related to clam harvesting and the interventions on the basin morphology could hamper or delay such ecosystem recovery. 


\section{ABBREVIATIONS}

$$
\begin{aligned}
& \text { Chl- } a=\text { Chlorophyll } a \\
& \text { DIN }=\text { Dissolved inorganic nitrogen } \\
& \mathrm{E}_{\mathrm{h}}=\text { Redox potential } \\
& \mathrm{N}=\text { Nitrogen } \\
& \mathrm{NH}_{4}^{+}=\text {Ammonium } \\
& \mathrm{NO}_{2}^{-}=\text {Nitrites } \\
& \mathrm{NO}_{3}^{-}=\text {Nitrates } \\
& \mathrm{Ox}=\text { Oxygen saturation } \\
& \mathrm{P}=\text { Phosphorus } \\
& \mathrm{PCA}=\text { Principal component analysis } \\
& \mathrm{RP}=\text { Reactive phosphorus }
\end{aligned}
$$

\section{ACKNOWLEDGEMENTS}

The authors thank the "Consortium for Coordination of Research Activities and concerning the Venice Lagoon System" (CoRiLa) that in part funded the lagoon measurements carried out in summer 2003. The authors are grateful to Dr. Orietta Zucchetta for the English editing.

\section{REFERENCES}

[1] Howarth RW, Anderson D, Cloern J, Elfring C, Hopkinson C, Lapointe B. Nutrient pollution of coastal rivers, bays, and seas. Issues Ecol 2000; 7: 1-15.

[2] Billen G, Garnier J, Deligne C, Billen C. Estimates of earlyindustrial inputs of nutrients to river systems: implications for coastal eutrophication. Sci Total Environ 1999; 243/244: 43-52.

[3] Billen G, Garnier J, Rousseau V. Nutrient fluxes and water quality in the drainage network of the Scheldt basin over the last 50 years. Hydrobiologia 2005; 540: 47-67.

[4] Coelho S, Gamito S, Pérez-Ruzafa A. Trophic state of Foz de Almargem coastal lagoon (Algarve, South Portugal) based on the water quality and the phytoplankton community. Estuar Coast Shelf S 2007; 71: 218-231.

[5] Izzo G, Moretti S. State and pressures of the marine and coastal Mediterranean environment, Denmark: European Environment Agency, Copenhagen, 1999; p. 137.

[6] Chiaudani G, Vighi M. Multistep approach to identification of limiting nutrients in northern Adriatic eutrophied coastal waters. Water Res 1982; 16: 185-192

[7] Chiaudani G, Gaggino GF, Vighi M. Synoptic survey of the distribution of nutrients in Italian Adriatic coastal waters. Thalassia Jugoslavica 1983; 19: 77-86.

[8] Pavoni B, Marcomini A, Sfriso A, Donazzolo R. In: Dunnette DA, O'Brien RJ, Eds. The Science of Global Change. Changes in an estuarine ecosystem: the lagoon of Venice as case study. Washington D.C. USA: American Chemical Society 1992; $287-$ 300 .

[9] Bianchi F, Ravagnan E, Acri F, et al. Variability and fluxes of hydrology, nutrients and particulate matter between the Venice Lagoon and the Adriatic Sea. Preliminary results (years 20012002). J Mar Syst 2004; 51: 49-64.

[10] Solidoro C, Pastres R, Cossarini G. Nitrogen and plankton dynamics in the lagoon of Venice. Ecol Model 2005; 184, 103-124.

[11] Ravera O. The lagoon of Venice: The result of both natural factors and human influence. J Limnol 2000; 59: 19-30.

[12] Sfriso A, Facca C, Ghetti PF. Temporal and spatial changes of macroalgae and phytoplancton in a Mediterranean coastal area: The Venice lagoon as a case study. Mar Environ Res 2003; 56: 617636.

[13] Pastres R, Solidoro C, Ciavatta S, Petrizzo A, Cossarini G. Longterm changes of inorganic nutrients in the Lagoon of Venice (Italy). J Mar Syst 2004; 51: 179-189.
Andreottola G, Cossu R, Ragazzi M. Apporti di nutrienti dal bacino scolante della laguna di Venezia: confronto tra metodi di stima diretti ed indiretti. Ingegneria Sanitaria 1990; 19: 176-185.

Bettiol C, Collavini F, Guerzoni S, et al. Atmospheric and riverine inputs of metals, nutrients and persistent organic pollutants into the lagoon of Venice. Hydrobiologia 2005; 550: 151-165.

Sfriso A, Marcomini A. Decline of Ulva growth in the lagoon of Venice. Bioresource Technol 1996; 58: 299-307.

Zonta R, Costa F, Collavini F, Zaggia L. Objectives and structure of the DRAIN project: an extensive study of the delivery from the drainage basin of the Venice Lagoon (Italy). Environ Int 2005; 31: 923-928

Zuliani A, Zaggia L, Collavini F, Zonta R. Freshwater discharge from the drainage basin to the Venice Lagoon (Italy). Environ Int 2005; 31: 929-938.

Cavazzoni S. Acque dolci nelle laguna di venezia. Technical Report 64, CNR-ISDGM, Venice, Italy, 1973; p. 33.

Pirazzoli P. Historical data on the mean tidal level in Venice (in Italian). Att A Sci I Bol 1974; 18: 124-148.

Umgiesser G, Melaku CD, Cucco A, Solidoro C. A finite element model for the Venice Lagoon. Development, set up, calibration and validation. J Mar Syst 2004; 51: 123-145.

[22] Oxner M. The determination of chlorinity by the Knudsen method and hydrographical tables. New York, USA: G. M. Manufactoring Co. 1962; p. 63.

[23] Strickland JDH, Parson TR. A Practical Handbook of Seawater Analyses. Fish. Res. Bd. Canada, Bull. No. 167, Ottawa, 1972; p. 310.

[24] Lorenzen CJ. UNESCO Technical Papers of Marine Science Determination of chlorophyll in sea water. 1967; 35-120.

[25] Sfriso A, Facca C. Distribution and production of macrophytes and phytoplankton in the lagoon of Venice: comparison of actual and past situation. Hydrobiologia 2007; 577: 71-85.

[26] Sfriso A, Facca C, Ceoldo S. In: Campostrini P, Ed. Scientific Research and safeguarding of Venice. Volume VI. Growth and net production of the seagrass Nanozostera noltii (Hornemman) Tomlinson et Posluzny in Venice lagoon. Corila, Venice, Italy 2008; 281-292.

[27] Sfriso A, Facca C, Ceoldo S, Marcomini A. Recording the occurrence of trophic level changes in the lagoon of Venice over the '90s. Environ Int 2005; 31: 993-1001.

[28] Lvov SN, Pastres R, Sfriso A, Marcomini A. In: Lasserre A, Marzollo A, Eds. The Venice Lagoon Ecosystem. UNESCO. Chapter 29. Far-from-equilibrium thermodynamic modelling of acquatic shallow environments. Carnforth, UK: The Parthenon Publishing Group 2000; 481-496.

[29] Widdicombe S, Spicer JI. Predicting the impact of ocean acidification on benthic biodiversity: What can animal physiology tell us? J Exp Mar Biol Ecol 2008; 366:187-197.

[30] Crouzet P, Leonard J, Nixon S, et al. Nutrients in European ecosystems. In: Thyssen N, Ed. European Environmental Agency, Copenahgen, Denmark, 1999; p. 156.

[31] Cossu R, de Fraja Frangipane E. Stato delle conoscenze sull'inquinamento della laguna di Venezia, Technical Report, Ministero dei Lavori Pubblici, MAV, CVN, Venezia, 1985; vol. 4.

[32] Solidoro C, Pastres R, Cossarini G, Ciavatta S. Seasonal and spatial variability of water quality parameters in the lagoon of Venice. J Mar Syst 2004; 51: 7-18

[33] Acri F, Bernardi Aubry F, Berton A, et al. Plankton communities and nutrients in the Venice Lagoon. Comparison between current and old data. J Mar Syst 2004; 51: 321-329.

[34] Sfriso A, Marcomini A, Pavoni B. Relationship between macroalgal biomass and nutrient concentrations in a hypertrophic area of the Venice lagoon. Mar Environ Res 1987; 22: 297-312.

[35] Facca C, Ceoldo S, Pellegrino N, Sfriso A. $9^{\text {th }}$ Littoral International Conference. Updating of sediment nutrient concentrations in the lagoon of Venice (summer 2003). Venice, Italy 2008.

[36] Facca C, Sfriso A, Socal G. Changes in abundance and composition of phytoplankton and microphytobenthos due to increased sediment fluxes in the Venice lagoon, Italy. Estuar Coast Shelf S 2002; 54: 773-792.

[37] Torricelli P, Boatto V, Franzoi P, Pellizzato P, Silvestri S, Eds Piano per la gestione delle risorse alieutiche delle lagune $\mathrm{di}$ Venezia e Caorle. Provincia di Venezia, Arti Grafiche Zotelli, Dosson di Casier, TV, Italy, 2009. 
[38] Sfriso A, Facca C, Marcomini A. Sedimentation rates and erosion processes in the lagoon of Venice. Environ Int 2005; 31: 983-992.

[39] Sfriso A, Facca C, Ceoldo S, Pessa G. In: Campostrini P, Ed. Scientific Research and safeguarding of Venice. Volume III.
Sedimentation rates, erosive processes, grain size and sediment density changes in the lagoon of Venice. Corila, Venice, Italy 2005; 203-213.

Received: August 5, 2010

Revised: September 10, 2010

Accepted: September 18, 2010

(C) Facca et al.; Licensee Bentham Open.

This is an open access article licensed under the terms of the Creative Commons Attribution Non-Commercial License (http://creativecommons.org/licenses/by$\mathrm{nc} / 3.0 /$ ), which permits unrestricted, non-commercial use, distribution and reproduction in any medium, provided the work is properly cited. 